\title{
THE 1998 UNIVERSITY OF WYOMING/GRAND TETON NATIONAL PARK COOPERATIVE ARCHAEOLOGY PROGRAM
}

\author{
CHARLES A. REHER \\ DEPARTMENT OF ANTHROPOLOGY \\ UNIVERSITY OF WYOMING \\ LARAMIE
}

\section{$\downarrow$ INTRODUCTION}

As of this writing we have completed the third year of a cooperative UW/GTNP archaeological project, with 1998 being the first season. The primary purpose here is to provide a brief overview of some of the accomplishments of that first field season. This basic "UW/NPS Research Center Annual Report" format then will have two more installments for 1999 and 2000. More attention is given in this first report to background such as the history of archaeological research in Grand Teton National Park, while subsequent reports will emphasize other types of information.

No attempt is made here to provide detailed discussions of field methods, project environmental settings, or individual sites, features, and artifacts. Such description would be standard in some archaeological reporting formats, but much more detailed discussions, and more synthesis of regional prehistory, is being assembled in a series of projectspecific compliance reports, conference papers, seminar papers, a graduate student thesis, and journal articles.

The possibility of a cooperative University of Wyoming/Grand Teton National Park venture was first proposed by Robert Schiller, Director of the Science and Resource Management Division at Grand Teton. It was apparent that a series of mutual benefits could result, where University archaeologists would aid the Park with its increasing number of federally-mandated compliance projects while at the same time providing student training and employment opportunities. In addition, nearly 400 sites had been located in Grand Teton National Park and the adjacent Rockefeller Parkway at that time, but very little current information was available for many of them and modern reevaluations were needed. At the same time, these various "applied research" compliance surveys and site revisit projects could contribute to broader theoretical frameworks relevant to our research throughout the region. The investigation of prehistoric settlement patterns and other aspects of landscape utilization is enhanced even by basic surface evidence, for example.

The 1998 UW/GTNP CAP crew included the writer, UW Anthropology graduate students Alan Bartholomew and Mike Peterson, and volunteer archaeologist Jill Anderson. All work in Grand Teton has been coordinated with Park Historian Mike Johnson and USFS/GTNP Archaeologist Merry Haydon. Dave Hammond with the GTNP GPS unit and several other individuals aided with our projects. Yellowstone National Park Archaeologist Ann Johnson provided needed advice and materials on several occasions. All of our work was only possible because of the availability of the AMK Science Camp facilities, and the hospitality provided there by Hank and Mary Ann Harlow and their staff. 


\section{High Altitude Adaptations}

It is assumed that most interested readers already are familiar with the ecology of the Greater Yellowstone Area, well beyond any brief synopsis that might be written down here. It might be noted that the nature of prehistoric (and early historic) adaptation to this high altitude environment has tended to be a main unifying theme for all archaeological research in the Greater Yellowstone Area. Whether Native American huntergatherers could even inhabit the area on a year-round basis is still a matter of debate. A heavy dependence on storage from specialized hunting and plant food processing would be required for a stay of any length during the cold season.

The incomplete understanding of resource complexes associated with major lake basins, the apparent affiliations with the populations of several surrounding regions (e.g. Northwest Plains, Great Basin, Plateau) and other factors add to the complexity of archaeological interpretation at Grand Teton. The active geological regimes and relatively poor site preservation also make archaeological research in the area more difficult.

Nevertheless, evidence from more than two decades has steadily added to both the details and to the broad theoretical considerations about how prehistoric people "lived off the land" in Jackson Hole. Radiocarbon dates, archaeomagnetic dates, and diagnostic artifacts have established a chronological framework extending back nearly 10,000 years. Most detailed research questions still depend on the excavation of stratified deposits that is the "bread and butter" of contemporary archaeology. Basic considerations of seasonal movement patterns first investigated more than 20 years ago now can be augmented with equation-based optimal foraging theory. Analysis of pollen, plant phytoliths, starch granules and other techniques can identify the exact plant types that were the being processed at a buried roasting pit, and so on.

Other standard methodologies now include Xray florescence analysis of obsidian artifacts, resulting in exact source attribution to a specific obsidian flow, and analysis of a site assemblage can "map out" movement patterns prior to the use and discard of the assemblage. Quantitative analysis of artifact orientations, sediment particles size, and other microstratigraphic data allows us to identify inherent limitations on what we actually should try to say about the occupational history of a given site deposit.
As just noted, surface evidence can contribute in at least a basic way to a broader understanding of prehistoric settlement strategies. The large samples of site locations discovered by surface survey are just what is what is needed here, although again follow-up excavation will always be an important component. Settlement pattern studies have two basic aspects, 1) trying to establish the mobility strategies of a specific ethnic group or time period, and 2) investigating the general and always patterned distribution of sites across the landscape that results from use of an area by different cultural groups or from all time periods. Different adaptive strategies can lead to different rates of mobility, more generalized or more specialized use the same plant and animal resources, and so on, but the most productive locations will always attract concentrated activity by any hunter-gatherer culture.

Previous work and our recent work continues to clarify these patterns. Early investigators noted the concentration of sites at lake inlets and outlets and in other lacustrine settings. The nature of sites in other settings along the Snake River terrace system and those of its tributary systems continues to emerge. Site settings such as benches and ridge tops well back from any drainages are also known, and the lack of sites at similar settings right at the foot of the Teton Range seems to be another pattern. Eventually, more detailed correlation with topographic and environmental data will allow testing of specific propositions about settlement patterns, and also confer systematic and accurate predictive capabilities.

\section{THE REGIONAL CRM SYSTEM}

Along the same lines the writer must assume some basic familiarity on the part of the reader with the EIS-based Cultural Resource Management (CRM) system. Environmental impact legislation and various archaeological resource protection acts have dictated that archaeological sites must be treated as "nonrenewable resources", and their "significance" must be "evaluated" and any proposed "adverse impacts" must be "mitigated". Site significance is legally defined by a series of conventions based on their ability to contribute information to a research design. Since all sites have at least some potential in this regard, evaluating significance is a practical matter saddled with a further series of conventions such as whether a given site is "eligible for nomination to the National Register of Historic Places" (once eligibility is established, an actual nomination is not necessary). 
Being tied to National Register guidelines originally intended for old buildings, the tendency to over-equate "site size " with "significance", and many other problems inherent in this process have been long debated, but these matters are beyond the scope of the discussion here. Suffice it to say that the system generally works, that sites are afforded protection on a regular basis, and that the need for such protection is a very common event even in more isolated places like Grand Teton National Park.

Fieldwork and reports are now part of a standard CRM cycle of "inventory survey" and "test excavation" wherein "nonsignificant sites" are usually afforded little or no protection while "significant sites" are protected through "avoidance", or mitigated by salvage excavation or other mitigation measures. This CRM cycle has been a multimillion dollar annual business in every state in the nation for more than two decades. Archaeologists from academic, state, federal, and commercial organizations coordinate their work with state, federal, and tribal regulatory structures to undertake the needed resource protection procedures. In a given season, for example, timber sales, various types of construction, and many other projects in the GYA might see month after month of fieldwork by a number of Forest Service archaeologists and BLM archaeologists from adjacent District Offices, along with work by National Park Service archaeologists stationed in the area. A crew from the NPS Midwest Archaeological Center of Lincoln, Nebraska might be working on these or other projects. Almost every year, state highway construction projects in the area will see NPS archaeologists and a Wyoming Department of Transportation archaeologist coordinating with crews from the Wyoming State Archaeologist as well as with archaeologists employed by CRM firms. Other types of construction will result in field activities by individuals and small crews from three or four different consulting firms, if not more, from several different states.

In addition, the work in Grand Teton National Park now might also utilize a small but highly experienced crew and field school students from the University of Wyoming. How to best integrate our recent entry into this region-wide endeavor is "what we are about" at this time. Seeking a balance between resource protection, scientific research, professional staff development, regulatory issues, the sponsor's financial considerations, and many other factors is tricky at best.

\section{ARCHAEOLOGICAL RESEARCH IN Grand TETON NATIONAL PARK}

If the writer may be pardoned for a bit of oversimplification, the University of Wyoming/Grand Teton National Park Cooperative Archaeology Program (UW/GTNP C AP) is basically the fifth phase in the archaeological history of Grand Teton National Park. Some of these phases were relatively discrete events, while others were more ongoing and/or overlapping. Earlier phases included work by the State University of New York (SUNY) (1970's-1980's) and a following set of years with the National Park Service Midwest Archaeological Center (NPS MWAC)(1980's-1990's). There also have been more sporadic but still definite contributions throughout this period by the University of Wyoming. A fourth phase can be seen in an ongoing set of CRM field projects by several commercial firms, by institutions such as Western Wyoming College, and by in-house NPS archaeologists (1990's-present).

A number of amateur collectors have tended to emphasize enlarging their personal collections, but these also have been "part of the mix". Also relevant to archaeological work by any organization in Grand Teton would be a useful but limited number of reports by ethnographers such as Shimkin (1947), who report how the Wind River (Eastern) Shoshone would travel into Jackson Hole during the summer for hunting and gathering of edible plants, along with other works such as Murphy and Murphy (1960) and Lohse and Holmer (1990) for the Fort Hall Shoshone-Bannock.

In spite of this amount of work, a researcher new to Grand Teton might gain the impression that we still need more updated and comprehensive summaries of what has been done and learned, and that we still lack a coherent theoretical approach to explaining the archaeological record in Grand Teton (this perception might need to be tempered a bit if we were to consider all of the previous GYA work). Research by SUNY and MWAC was consistent across a set of years but, in the long run, still somewhat episodic. When such teams do several years of significant work and then move on, they cannot help but leave behind something of a hiatus. The expertise and familiarity gained by these highly qualified professionals is available to subsequent researchers only in the form of condensed site forms and reports, and a great deal is lost in the translation.

Recent CRM projects have added steady contributions, but these necessarily are relatively small and project-specific. The need for a more coherent and comprehensive research design for all archaeological 
work in the park was recently noted by new Grand Teton Cultural Resource Division Director Greg Kendrick. Whether the new UW/GTNP Cooperative Archaeology Project can contribute to this design, and do more than add yet another "episode", remains to be seen.

The first year (1998) of UW/GTNP CAP was a modest start and indeed a bit of a "shakedown cruise". We were able to go to about 16 locations, finding 14 new sites or features and revisiting 30 previously known sites (see Fig. 1). The design of the project has continued to evolve, but hopefully it can be demonstrated that it has had some success since that first season. At this writing, the first 3 field season have taken us to more than 40 locations, as described in more than 20 reports. Included by now are revisits nearly 70 previously known sites and the discovery of more than 50 new sites. Theoretical frameworks have been refined, and the writer continues to upgrade this aspect of the work as our familiarity with the Park grows.

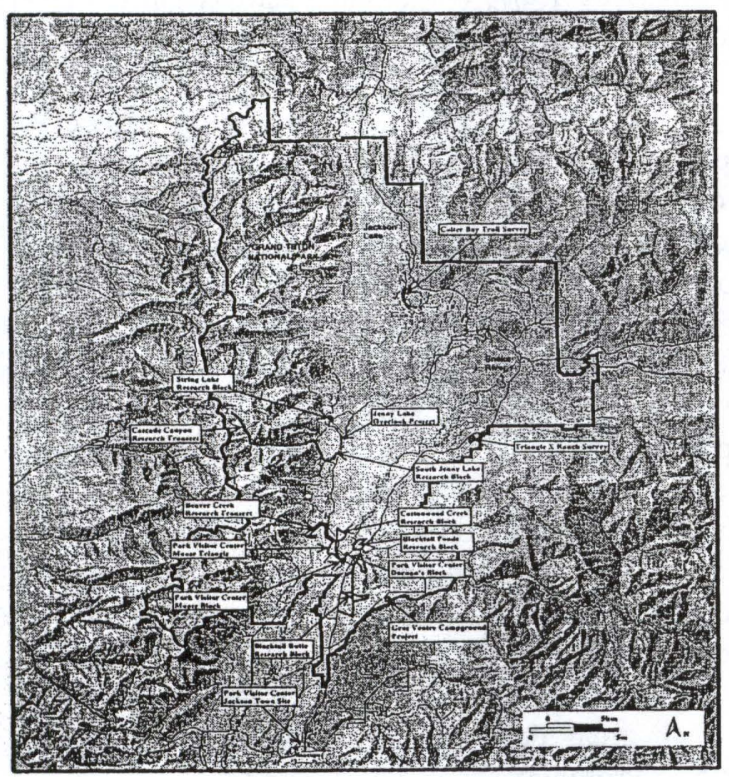

Fig. 1 - 1998 UW/GTNP Cooperative Archaeology Project Locations.

\section{$\downarrow$ OVERVIEW OF PREVIOUS ARCHAEOLOGICAL INVESTIGATIONS}

Grand Teton National Park and Jackson Hole have been the subject of numerous archaeological investigations for nearly 30 years. Occasional professional visits and contributions by avid avocational archaeologists go back even further. As was noted above, this effort is still coalescing because of somewhat episodic research and several other factors. The active geological contexts in this high altitude area clearly are not conducive to the best sort of site preservation. Erosion from extremely active spring runoff and active wave erosion along lake margins is typical. Long stretches of shallow and rocky Holocene terraces and other geological contexts that do not lend themselves to the preservation of stratified deposits are common.

Along the same lines but in something of an opposite sense, we often do not find the highly localized erosion and lack of ground cover that exposes at least the edges of sites elsewhere, allowing their discovery. There are large patches of eolian deposits in Grand Teton but they tend not to have the blowout exposures one might see elsewhere. Dense stands of grass and widespread leaf and needle litter, and the occasional occurrence of exceptionally deep Holocene deposits, also do not allow for good surface visibility. It has been estimated that the artificial raising of Jackson Lake submerged more than 100 archaeological sites, including apparently including the largest and most dense sites in the Park. These were studied during a brief period of lowered water in the early 1990's (see below), but they since then been inaccessible for any and all new research objectives. The Jackson Hole area is generally subsumed within the Northwestern Plains region as described by Mulloy (1958) and Frison (1991), and the chronological frameworks outlined by Frison can be applied reasonably well (e.g. Paleoindian, Early, Middle and Late Plains Archaic, etc.). However, there has been a growing awareness that the Jackson Hole archaeological record also may have affinities with the Plateau to the northwest and the Great Basin to the southwest. Dating of diagnostic artifacts, establishing possible ethnic identity, characterizing settlement strategies, and other standard archaeological considerations are more complex as a result. Work in Grand Teton is limited somewhat by the state of research along the adjacent margins of these major regions and the type and amount of published work can vary a great deal.

Recently, several researchers have moved
toward trying to understand a Rocky
Mountain/Intermountain Basin zone in the central part
of the continent as a "culture area" in its own right, with
year-round high altitude occupations and where
"affiliations" with surrounding regions are not as
important in understanding cultural histories (e.g. Black
1991; Kornfeld and Larson 1993, 1994; see also
Benedict and Olson 1978; Benedict 1992; Frison 1976;
Frison and Grey 1980).




\section{UNIVERSITY OF WYOMING}

Work by the University of Wyoming would seem to be a logical place to start a discussion of the history of research in the state of Wyoming, although our prior involvement has been somewhat sporadic and project-specific, as was noted above. Work by UW does reflect among the earliest and overall the longest time span, so it is described first here. Various reconnaissance by Frison led to mentions of obsidian sources and other information in regional overviews $(1978,1991)$, and a thesis by Love (1972) was among the first and most comprehensive professional reviews for the area. Love tended to view occupation of the Jackson Hole basin as seasonal in nature. Being from Jackson, Love was especially knowledgeable about the area but not able to continue archaeological work there.

Mentions in other regional overviews continued, and a fairly extensive but short-term search for Paleoindian (late Pleistocene) deposits took place when Jackson Lake water levels were lowered (Frison 1981, 1982; Frison, Eckerle, Adams and Ingbar 1989; Frison, Ingbar and Eckerle 1988). The work was coordinated with the ongoing NPS MWAC Jackson Lake Project, but in the long run neither organization could locate any substantial Paleoindian site deposits.

This interest in this potential for older site deposits at Jackson Lake was due to the numerous Paleoindian diagnostics that had been collected there decades earlier by local amateur Slim Lawrence. This large collection is housed in a local museum, and it was the subject of a paper by UW student Mike Peterson (1991). His study provided useful information on chronological morphology, possible affiliations with other regions, and other topics (work with this and other local collections continued during a current thesis project by another UW graduate student, Alan Bartholomew, as is discussed below). Work by another UW student, Rich Adams, led to a thesis and conference papers that mention use of steatite (soapstone) by more recent Native American cultures in Jackson Hole and in other high altitude zones (e.g. Adams 1993)

The search for Paleoindian materials continues as a major theme in the study of high altitude adaptations throughout the Greater Yellowstone Area. An ancillary UW/GTNP CAP project during the 1999 season that might be previewed at this juncture was another geoarchaeology reconnaissance led by Bob Kelly (1999). Kelly, the writer, and graduate students Clint Crago and Alan Bartholomew used surface survey and auger probes to locate and test deposits in the Potholes area, segments of the Snake River terraces, terraces along Pacific Creek, the outlet of Two Ocean Lake and Leigh Lake, Hedrick Pond, and Ditch Creek, and revisited known site areas at Kelly Warm Springs and Blacktail Butte. A number of paleosols were dated, but all proved to be ca. 3500 - 1000 years old, i.e. not Late Pleistocene/Early Holocene in age.

Although somewhat tangential, a dendroecology project by the writer and graduate students Peterson and Laura Scheiber added to our understanding of the ecology of the area (Reher and Scheiber 1995). Significant differences between flood plain tree stand age structure and growth rates where the Snake River had been channelized and leveed and those in undisturbed areas in Grand Teton Park were found. When combined with yet more relevant studies of fire return ecology, pollen studies and other studies, a more informed stance on prehistoric cultural ecology is available to archaeological investigators (cf. also Baker 1970; Barnosky 1987; Cummings 1989, 1996; Gish 1986; Scott 1987; Waddington and Wright 1974; Whitlock and Bartlein 1993).

A recent and large UW excavation project took place when the U.S. Fish and Wildlife service needed to construct new facilities at its Fish Hatchery next to the Elk Refuge outside of the town of Jackson (Larson 1995a). Directed by Mary Lou Larson, Marcel Kornfeld and David Rapson, the Henn Site (48TE1291) excavations took place at the behest of USFW Archaeologist Rhoda Lewis, and it was another example of the CRM system discussed above. Although basically a salvage operation to allow expansion of parking facilities, it was beyond a doubt the most highly controlled excavation yet conducted in Jackson Hole, and it resulted in far and away the most detailed report ever done for the area.

A great deal was learned about the Late Prehistoric-Protohistoric occupation of the area, since the Henn Site apparently represented an early 1800's Shoshonean processing location. Large roasting pits, 1600 fragments of butchered bone, over 5100 pieces of chipped stone, and several thousand fragments of firecracked rock were recovered in the main subsurface component. An Archaic component (or set of components) was much more ephemeral, but an Early Archaic diagnostic artifact and obsidian hydration data indicate another use of the site area that might go back nearly 7000 years (Larson and Rapson 1995).

An increased understanding of the role of large roasting pits resulted from this work, as did an 
expanded consideration of geological and biological (i.e. noncultural) site formation processes. This latter research framework is one that has not been applied enough to the poorly defined stratigraphy found at most sites in Grand Teton National Park. The work of geoarchaeologist Jim Miller was very important in this regard (Miller 1995), while Rapson (1995a) provided an important and detailed report on faunal materials (which are usually poorly p reserved in $\mathrm{h}$ igh a ltitude settings). The X-ray florescence spectral analysis of obsidian sources was spearheaded by Kunselman, and combined with unusually detailed analysis of firealtered rock (Kunselman, Kornfeld and Miller 1995). Consultants were used to garner information on pollen and phytoliths (Fredlund 1995), obsidian hydration, archaeomagnetic dating and other topics (cf. Kornfeld and Rapson 1995). Other chapters considered chipped stone technological organization (Larson 1995b), site spatial structure (Rapson, Kornfeld and Larson 1995), fire hearth features (Rapson 1995b), and so on.

Various 1998-2000 UW/GTNP CAP projects are discussed in more detail below. A Masters thesis by Bartholomew was another result of the program and this manuscript is now near completion (Bartholomew n.d.) This thesis will most definitely be a major step in synthesizing of the archaeology of Grand Teton National Park. All of the UW/GTNP CAP work appears to now be becoming somewhat comparable to the work established by SUNY and the Midwest Center, adding another major component to the history of investigations in Grand Teton.

\section{STATE UNIVERSITY OF NEW YORK ALBANY}

Returning to the earlier history of archaeological investigations in Grand Teton, individuals from SUNY formed a prominent team in the late 1970 's and early 1980 's, including Stuart Reeve, Gary Wright, Susan Bender, and others. They produced a series of research reports, articles, theses and dissertations (e.g Reeve 1976, 1983, 1986; Wright 1975, 1984; Marceau 1976; Bender 1983; Wright and Marceau 1977; Wright and Reeve 1976; Wright and Marceau 1977; Bender and Wright 1988), including some publications which stretched out for some years after the actual fieldwork. They worked in a number of areas and some of their work in high altitude areas (i.e. well up into the Teton range) is still all that is available for that zone. Eventually, however, their actual fieldwork was rather distinctly truncated.

The SUNY team did make significant progress in locating large sites with some deposition around the inlets and outlets of major lakes such as Jenny Lake and Two Ocean Lake, and they also explored quartzite quarries on Blacktail Butte and other site types. They did extensive reconnaissance surveys and many of the site locations in Grand Teton are still known only from the brief site forms which they compiled. They provided a series of radiocarbon dates, documented numerous diagnostic projectile points, and information of other kind.

Much of their more synthetic work converged on trying to understand prehistoric settlement patterns and seasonal movement patterns. As with most of the archaeological perspectives at the time, they tended at first to view mountainous zones as somewhat marginal, and inhabited only seasonally by migrants from lower intermontane basins. They discussed how these groups would shift through a series of base camps and secondary limited activity procurement sites as the season progressed, following the ripening of specific plants at increasing altitudes while also incorporating new resources in the diet (Bender 1983; Wright 1984). They discussed the consequences of this model for tool assemblage diversities in the two types of site, and predicted that the procurement sites could be identified by their much more specialized assemblages.

In some earlier writings these investigators were more concerned with specific, high return rate resources known to be important in surrounding regions. Marceau (1976) called attention to the potential of aquatic resources such as the cutthroat trout, while Reeve (1983) was interested in the role of Blue Camas and other root crops. In later writings, some of these authors do discuss more of a broad spectrum resource use while still emphasizing a warm season occupation (Bender and Wright 1988).

\section{NATIONAL PARK SERVICE MIDWEST CENTER}

Subsequent to the SUNY efforts a substantial amount of work has been done by the NPS Midwest Center, based in Lincoln, Nebraska. Essentially all their projects were involved with cultural resource management projects. These ranged from various small projects with accompanying brief standardized reports to a comprehensive set of annual reports of the "Jackson Lake Project" by Melissa Conner and others (e.g. Conner 1990a, 1995, 1998). These investigations at several sites exposed when Jackson Lake was lowered for dam repairs provide subsurface debitage densities and other data that continue to be useful. Much of the work was concentrated at the "Lawrence Site" (48TE509), perhaps the largest site in Jackson 
Hole. Work in the Jenny Lake developed area also was substantial and included small test excavations, carbon dates, and so on (cf. Winfrey 1991, 1994; Conner 1990b, 1992a, 1992b, 1995, Connor, et al 1998, Conner et al 1998).

For the most part, the MWAC researchers continued to build on the settlement patterns models offered by the SUNY group. Sites are interpreted in terms of their basic function, e.g. base camps, short term base camps, limited activity sites, and so on (cf. Conner 1998). Large roasting pits found on the floor of Jackson Lake were examined in terms of their role in processing tubers, such as had been discussed by Wright and others. Overviews of projectile point typologies and chronology, research on paleoclimatic change, and other synthetic and ancillary work also was produced (e.g. Calabrese and Svee 1987; Scott 1987; Matz 1988; Conner 1998).

Kenneth Cannon and various collaborators affiliated with MWAC as well as other investigators have contributed work specifically on the role of bison in prehistoric subsistence for the GYA and Jackson Hole, although less so for Grand Teton specifically, since the end of the MWAC Jackson Lake Project) (e.g. Cannon 1988, 1991, 1997, 1999, n.d.). Other important work has included new overviews of GYA chronology (Cannon and Schoen 1993), obsidian sourcing by USFS archaeologist James Schoen (1997); Conner and Kunselman (1997) and various other aspects of reporting on a couple of excavation site near to the Park (Cannon, Eckerle, and Pierce n.d.; Cannon and Sittler n.d.; Sittler and Cannon 2000).

\section{$\uparrow$ AdDITIONAL PROJeCtS}

A small scattering of CRM projects are pretty much all that remains for any overview of archaeological investigations in Grand Teton National Park (e.g. Truesdale 1994; Quick 1996; Johnson 1997); various site forms and other information and documents in our files also denote projects by the CRM service group at Western Wyoming College. A few more are added to this list each season, including a series of projects currently being documented by USFS/NPS archaeologist Merry Haydon, and these will be noted in more detail in subsequent reports. These reports often encounter little or no archaeological evidence since their location is determined by construction rather than archaeological priorities, but when something is found, it adds to our study of settlement locations, chronology and other topics.

\section{THE UW/GTNP COOPERATIVE ARCHAEOLOGY PROJECT}

The 1998 season of UW/GTNP CAP began with a backlog of standard CRM surveys. For several with higher priorities we were able to complete the fieldwork and turn in a brief report during the field sessions. Fieldwork took place primarily in the southern end of the park, although there was one project to the north along Colter Bay on Jackson Lake (see Fig. 1) (Bartholomew, Peterson and Reher 1999a-b, 2000; Peterson, Bartholomew and Reher 1998a-c; Bartholomew and Reher 1998, 1999a-b).

The practicalities of the 1998 work contributed to planning and development of additional components which were added in 1999 such as an undergraduate archaeological field school, the Late Pleistocene/Early Holocene g eoarchaeological research reconnaissance (Kelly 1999), and a definite expansion of the basic inventory, site revisit and test excavation phases of the project (see 1999 and 2000 Annual Reports; also Bartholomew and Reher 1999c, 2000a-k). During 1999 and 2000 , a series of public presentations, conference papers, and a Master's thesis project also were initiated (Reher et al 2000; Bartholomew n.d.). Other public education initiatives also have been discussed (e.g. interpretive displays at UW and at Grand Teton facilities).

The 2000 season concentrated on an extensive mapping and test excavation project at the Cow Lake Site (48TE1536), an interesting and still not completely understood Early Historic tipi ring site (Reher et al 2000). This project had more of a research orientation, although it also was part of our general documentation and evaluation of archaeological resources in the Park. A full report with detailed artifact analysis and other information is forthcoming, and this will go far beyond the basic CRM survey report produced when the site was first found (Bartholomew and Reher 2000k).

Although a few of our endeavors were only in the planning and/or proposal stage during 1998, their general nature should be summarized as seen in Table 1 in order to convey here the overall scope of UW/GTNP CAP. Pedestrian survey methods and site recording methods have been continually upgraded. Standardized surface lithic coding formats and forms, a site documentation procedural manual, upgraded report maps and graphics, and other materials were developed (e.g. Bartholomew and Reher 1999d). NPS personnel also cooperated with UW/GTNP CAP crews in the use of more accurate GPS equipment to record site 
boundaries.

An overall research outline also has been under development (again, as outlined in Table 1), ranging from standard considerations such as refining regional chronologies, to more specific questions about prehistoric settlement patterns and changes in occupational intensity through time. Detailed site formation processes studies such as developed for the Henn Site (48TE1291) (Miller 1995; Larson 1995; Rapson, Kornfeld and Larson 1995) cannot be applied during surface surveys and small test excavations, but they did provide guidance as surface/subsurface debitage density ratios were compared, as other site information was gathered, and as sites were evaluated. The Cow Lake Project has brought on much more detailed considerations of historical, ethnographic, and Tribal oral history resources, and these studies now too are underway. Lithic source analysis, studies of quarry site use and other related frameworks were also established.

\begin{tabular}{|l|}
\hline $\begin{array}{l}\text { Table } 1 \text { - UW/GTNP Cooperative Archaeological } \\
\text { Program Structure }\end{array}$ \\
\hline Small Compliance Surveys \\
\hline \\
\hline Medium-Large Compliance Survey Blocks \\
\hline $\begin{array}{l}\text { Inventory and Evaluation Surveys for High } \\
\text { Visitation/Development Zones }\end{array}$ \\
\hline \\
\hline $\begin{array}{l}\text { Site Revisits, Documentation Upgrades, and Re- } \\
\text { evaluations }\end{array}$ \\
\hline Reconnaissance Survey Transects \\
\hline \\
\hline University Archaeological Field School \\
\hline \\
\hline Research Assistant Employment and Training \\
\hline \\
\hline $\begin{array}{l}\text { Conference Presentations, Publications, Technical } \\
\text { Reports }\end{array}$ \\
\hline \\
\hline Master Thesis Research Projects \\
\hline \\
\hline Site-Specific Research Projects \\
\hline \\
\hline Geoarchaeological Research Projects \\
\hline Public Education Initiatives \\
\hline
\end{tabular}

\begin{tabular}{|l|}
\hline \\
\hline Research Design Development \\
\hline Chronology Refinement \\
\hline Site Formation Processes \\
\hline $\begin{array}{l}\text { Prehistoric Cultural Ecology, Subsistence and } \\
\text { Settlement Patterns }\end{array}$ \\
\hline Measuring Prehistoric Occupational Intensity \\
\hline Late Pleistocene/Early Holocene Geoarchaeology \\
\hline $\begin{array}{l}\text { Protohistoric/Early Historic Native American Land } \\
\text { Use }\end{array}$ \\
\hline Tribal Ethnohistory \\
\hline Tribal Oral Traditions \\
\hline $\begin{array}{l}\text { Early Historic Trash Discard Patterns, Subsistence } \\
\text { and Settlement Patterns }\end{array}$ \\
\hline Local History \\
\hline $\begin{array}{l}\text { Archaeologically Relevant Topographic, Ecological } \\
\text { Stratification }\end{array}$ \\
\hline Computer, GIS Applications \\
\hline
\end{tabular}

\section{THE 1998 FIELD SEASON}

The 1998 UW/GTNP Archaeology Project had three very basic objectives:

1) small and medium-sized surface inventory clearance surveys for specifically identified development project, and other inventories to provide more generalized evaluations for zones where development of various types might take place, or where public visitation was having an increasing impact;

2) revisits to previously recorded sites in order to provide more current evaluations of their size, richness, and state of preservation;

3) whenever possible, an attempt to combine the first two tasks with the reconnaissance of new areas via intervening survey transects.

Most of the 1998 work took place in the southern half of the Park, with the exception of one project at Colter Bay on the northern end of Jackson Lake (Fig. 1). The first field season was limited to essentially a couple of weeks in the field and we had to develop a familiarity with the Park landscape and the practicalities of Park procedures. In spite of this, we were able to inventory 8 small to medium survey blocks as part of 6 compliance related projects (Fig. 1, Table 2). Seven new sites or isolated features were found and 3 previously recorded sites were revisited. Eight more Park areas were the location of reconnaissance transects and site revisits, resulting in the discovery of 6 new 
sites or features and revisits to 27 known sites. Thus a total of 16 locations were visited, 14 new sites or features were found, and 30 known sites were revisited.

\begin{tabular}{|c|c|c|c|c|}
\hline $\begin{array}{l}\text { Project Area } \\
\text { Compliance } \\
\text { Surveys } \\
\end{array}$ & New Sites & Site Type & $\begin{array}{l}\text { Revisited } \\
\text { Sites }\end{array}$ & Site Type \\
\hline $\begin{array}{l}\text { Jackson Hole } \\
\text { Visitor's Center }\end{array}$ & - & - & - & - \\
\hline $\begin{array}{l}\text { Jenny Lake } \\
\text { Overlook }\end{array}$ & - & - & - & - \\
\hline $\begin{array}{l}\text { Colter Bay Trail } \\
\text { Rehabilitation }\end{array}$ & - & - & - & - \\
\hline $\begin{array}{l}\text { Gros Ventre } \\
\text { Campground }\end{array}$ & 48TE1459 & $\begin{array}{l}\text { lithic } \\
\text { procurement, } \\
\text { processing } \\
\text { station }\end{array}$ & - & - \\
\hline $\begin{array}{l}\text { Triangle } X \\
\text { Ranch }\end{array}$ & $\begin{array}{l}967 \text { (new } \\
\text { features) }\end{array}$ & $\begin{array}{l}\text { early historic } \\
\text { trash scatter }\end{array}$ & 967 & $\begin{array}{l}\text { Triangle X } \\
\text { Ranch }\end{array}$ \\
\hline $\begin{array}{l}\text { Moose Visitor } \\
\text { Center - } \\
\text { Dornan's Block }\end{array}$ & $\begin{array}{l}901 \text { (new } \\
\text { features) }\end{array}$ & $\begin{array}{l}\text { early historic } \\
\text { foundations }\end{array}$ & 397 & $\begin{array}{l}\text { lithic } \\
\text { scatter, } \\
\text { small } \\
\text { campsite }\end{array}$ \\
\hline & $\begin{array}{l}901 \text { (new } \\
\text { features) }\end{array}$ & $\begin{array}{l}\text { lithic/FCR } \\
\text { scatter }\end{array}$ & - & - \\
\hline $\begin{array}{l}\text { Moose Visitor } \\
\text { Center - Moose } \\
\text { Block }\end{array}$ & 1484 & $\begin{array}{l}\text { early historic } \\
\text { foundations, } \\
\text { trash scatters }\end{array}$ & - & - \\
\hline \multirow[t]{2}{*}{$\begin{array}{l}\text { Moose Visitor } \\
\text { Center - Moose } \\
\text { Triangle }\end{array}$} & 1482 & $\begin{array}{l}\text { early historic } \\
\text { foundations }\end{array}$ & 398 & lithic scatter \\
\hline & 1483 & $\begin{array}{l}\text { lithic } \\
\text { procurement }\end{array}$ & - & - \\
\hline $\begin{array}{l}8 \text { - project } \\
\text { areas }\end{array}$ & $\begin{array}{l}7 \text { - new } \\
\text { sites/features }\end{array}$ & & $\begin{array}{l}3-\text { site } \\
\text { revisits }\end{array}$ & - \\
\hline \multirow{5}{*}{$\begin{array}{l}\text { Blacktail Butte } \\
\text { West } \\
\text { Reconnaissance } \\
\text { and East } \\
\text { Revisits }\end{array}$} & 1486 & $\begin{array}{l}\text { early historic } \\
\text { trash, lithics }\end{array}$ & $350-354$ & $\begin{array}{l}\text { lithic } \\
\text { scatters, } \\
\text { stone circle }\end{array}$ \\
\hline & 1487 & $\begin{array}{l}\text { lithic } \\
\text { procurement, } \\
\text { scatter }\end{array}$ & 381 & $\begin{array}{l}\text { lithic } \\
\text { scatter, } \\
\text { campsites }\end{array}$ \\
\hline & 1488 & lithic scatter & $385-388$ & $\begin{array}{l}\text { lithic } \\
\text { scatters, } \\
\text { campsites }\end{array}$ \\
\hline & 1489 & $\begin{array}{l}\text { lithic scater, } \\
\text { small camp }\end{array}$ & 391 & $\begin{array}{l}\text { lithic } \\
\text { scatter, } \\
\text { campsites }\end{array}$ \\
\hline & 1490 & $\begin{array}{l}\text { early historic } \\
\text { trash }\end{array}$ & $\begin{array}{l}400, \\
401 / 523 \\
402\end{array}$ & quarries \\
\hline $\begin{array}{l}\text { Cascade } \\
\text { Canyon/Lake } \\
\text { solitude }\end{array}$ & - & - & - & - \\
\hline $\begin{array}{l}\text { Snake River } \\
\text { Terraces/ } \\
\text { Blacktail Ponds, } \\
\text { Cottonwood } \\
\text { Creek }\end{array}$ & $\begin{array}{l}405 \text { (new } \\
\text { features) }\end{array}$ & & 405 & $\begin{array}{l}\text { lithic } \\
\text { scatter, } \\
\text { campsite } \\
\text { early } \\
\text { historic }\end{array}$ \\
\hline
\end{tabular}

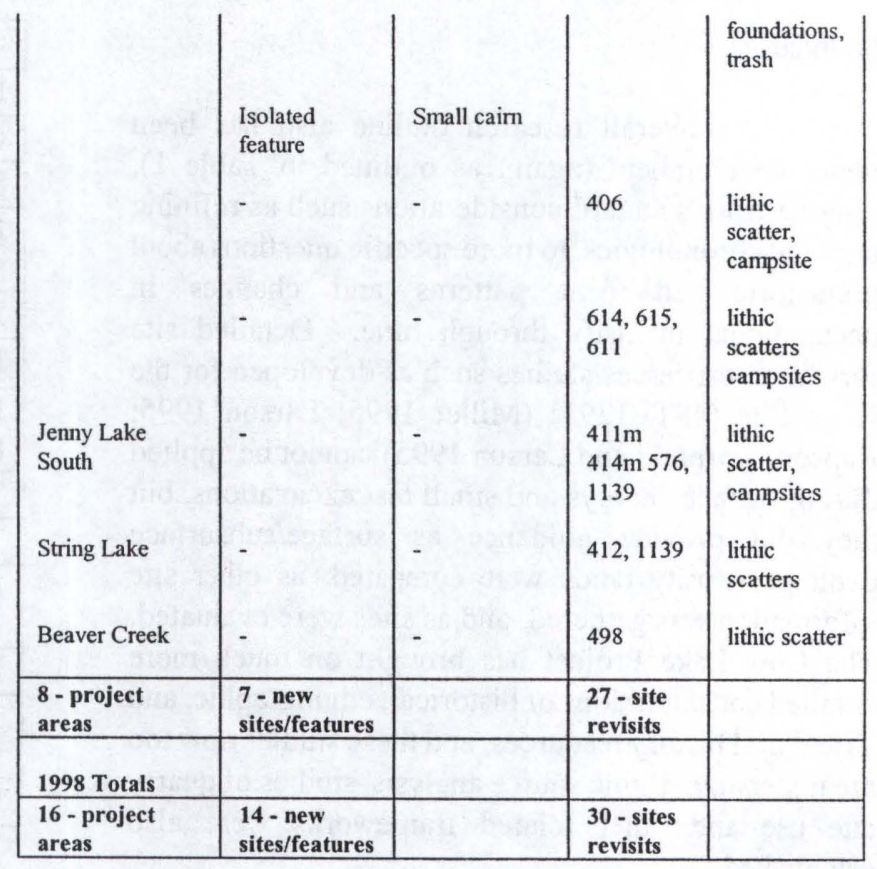

The "project areas" mentioned above and listed in Table 2 are used in a somewhat flexible manner to indicate separate surface survey locations. Two or three of them might be part of the same compliance project or general reconnaissance, however, e.g. 3 fairly closely spaced survey blocks that combined made up the Moose Visitor Center compliance survey. The Blacktail Pond and Cottonwood reconnaissance blocks were surveyed to revisit sites along a certain stretch of the Snake River, but they were about a mile apart and on opposite sides of the river. As another example, one project area in the 1998 Blacktail Butte reconnaissance was a complex set of transects designed to maximize revisits to known sites, and it stretched out south of and along the west side of the butte for $11 \mathrm{~km}$ (7 miles). A revisit to several known sites on the east/southeast part of Blacktail Butte was separated enough that it should be considered as a different project area.

Site revisits were an important part of our charge from Grand Teton National Park. Nearly 400 sites had been recorded for Grand Teton National Park and the adjacent Rockefeller Parkway, but many were first found two decades ago or more, and a one-page, mimeographed "lithic scatter" site form and a "dot on a map" might be all that was available. Even sites that have been restudied more recently have been subject to impacts and changes of various kinds, and an updated evaluation was crucial for management purposes. Eventually, our work will contribute to a NPS Rocky Mountain Region Site Status database. 
The majority of the more than 50 sites we have revisited needed some fairly definite change or addition to the original evaluation. Almost all are still in good state of preservation, but many are larger and more complex than was once thought. A few others have had detrimental impacts, or we found no c urrent surface evidence, or there was some other relevant modification needed.

Standard field methods were used for most project areas and project types. Intensive zig-zag pedestrian transects were aligned according to either compass bearings or topographic structure. Spacing between surveyors ranged from 5 to 30 meters depending on the purpose of a given survey. Upon being encountered, sites were given much more intensive coverage and pinflags were used to mark all surface artifacts and features. Inventories listing lithic material type, apparent stage of reduction, and other information were integrated with field map index numbers showing the artifact locations. Sites also were placed on USGS Quad maps, UTM coordinates were established for site boundaries using handheld GPS units, Wyoming Cultural Property Forms were filled out and detailed sketch maps were produced. Selected diagnostic artifacts were occasionally collected for subsequent documentation and analysis, but a nocollection policy was the most common policy. Shovel testing was not commonly employed because a final determination of eligibility was not needed prior to some sort of direct impact from construction, etc.

Standard, fairly short reports are compiled after the field season, with comments on project location, local environment, field methods, artifacts, recommendations, and other information (see relevant citations below). As would be expected by anyone familiar with the CRM cycle, the site forms and other documentation for new or revisited sites accompanying are voluminous, and several hundred pages of documents have been produced as a result of just the 1998 and 1999 seasons.

Although certain advantages accrue when one is able to inventory a standard "legal description" (e.g. the "NW 1/4 of Sec. 16"), or when a survey is based on a "100 meter wide-transect aligned on True North", this has usually not been the case in our work at Grand Teton. Such quadrant are easier for a land manager to incorporate in planning or archival purposes, and the research archaeologist can more easily convert use a known sampling fraction for statistical evaluation of site densities. However, our projects have been dictated by an irregular construction zone or the shape of an existing walking trail complex, or where new sites are likely to be exposed along a meandering terrace cutbank or other considerations. As even this less regularized coverage accumulates, it does gradually allow us to generate testable propositions about prehistoric landscape use, and we still hope to do this in an increasingly systematic way in the future.

\section{$\downarrow \quad$ COMPLIANCE SURVEYS}

\section{Jackson Visitor's Campus and Jenny Lake Overlook}

The clearance surveys defined by GTNP personnel included small projects such as a possible building site next to the existing visitor's center in Jackson Hole, and an expanded overlook parking turnout on the shore of Jenny Lake. The visitor center building was confirmed to be in an already disturbed and/or marshy urban-edge setting, and the Jenny Lake turnout was restricted to steep, rocky zone with no terrace, slope, or beach deposits, so no archaeological potential existed in either case (see Table 2; Peterson, Bartholomew and Reher 1998a, 1998b).

\section{Colter Bay Trails and Gros Ventre Campground}

The Colter Bay Trails project and Gros Ventre campground were somewhat more sizeable, e.g. an irregular survey area ca. 500 meters across at the Gros Ventre Campground to incorporate the proposed construction zone and a site which extended out from it (Peterson, Bartholomew and Reher 1998c; Bartholomew and Reher 1999a). No cultural resources were found in the areas designated at Colter Bay for trail rehabilitation, while one large but shallow lithic and fire-cracked rock scatter was found at the Gros Ventre Campground. Shovel testing was utilized to determine site boundaries, and to confirm that there was almost no deposition, with site materials being directly on the underlying alluvial cobble bed. Testing and procurement of quartzite cobbles seemed to be the main activity, with the FCR and a partial grinding slab indicating that other processing activities also took place. Only one smallish corner of the site would be impinged by the proposed construction, and it was not thought to be significant.

\section{Triangle X Ranch}

A similar compliance survey was conducted to allow work on facilities at the Triangle $\mathrm{X}$ dude ranch (Bartholomew and Reher 1998). Whereas only a small, specific location was needed, we find it much more efficient to provide clearance for as large a block as is 
possible, such that repeated small surveys might not be needed in the future (commercial CRM firms for obvious reasons don't always look at it this way, and federal archaeologists are sometimes constrained by practical or procedural policies). About 45 acres was surveyed for this project after this area was identified by the ranch operators as the most likely zone for any future ground disturbance, and complete clearance is now recommended for almost all of it.

The Triangle X Ranch itself is on the National Register of Historic places as a historic site (48TE967), and several previous archaeological surveys had been conducted or in the vicinity. Prehistoric sites are known to occur on nearby ridges from reconnaissance conducted by Wright in 1974 (48TE440, 441) while three surveys by National Park Service archaeologists found no cultural resources. Two early historic irrigation systems and two foundations had been identified during other surveys (48TE1333, 1334, 1321, 1322).

Several of the surveys either missed 6 early historic trash scatters or, in a couple of cases, apparently had relegated them to being "recent trash." Diagnostic artifacts among the several hundred that could be viewed showed that much of the dumping was sufficiently old to be legally eligible as an archaeological resource (e.g. late 1800's to early 1900 's). Such materials often do not get the attention they deserve, either by historians more concerned with documents or architecture, or by inexperienced archaeologists, but they can contribute to the significance of a site such as Triangle $\mathrm{X}$. The trash materials have general historical archaeological significance in their own right because of the information inherent in them, and more specifically they can contribute to the investigation of early ranching life in Jackson Hole. Avoidance or further study of these trash midden areas should become part of the management policies for Triangle X Ranch.

\section{Moose Visitor Center}

The largest and most complex survey took place at the Moose Visitor Center. GTNP planned a new visitor center building at the site, although an construction location could not be specified when we were there. Park personnel requested an inventory survey of the three most likely zones so that their general feasibility for new construction could be evaluated. More detailed survey in the area also would be generally useful since it is one of the busier and more developed areas in the Park. Two subrectangular blocks and one triangular block were identified, termed the Dornan's block (from nearby visitor facilities), the Moose Block (near to Moose Junction on Highway 26), and Moose Triangle (a triangular, relatively flat zone between the Moose-Wilson Road and the Teton Park Road northwest of the current visitor center). More than 200 acres was surveyed as a result of the requested project (Batholomew, Peterson and Reher 2000)..

Three new sites were located, including a large historic trash scatter with associated foundations (48TE1484). Several hundred items were flagged and mapped, including a number of artifacts with maker's marks, etc. that dated the site to the early 1900 's. The site had some characteristics of early historic trash middens from a nearby habitation, but melted slag and nonhabitation foundations also gave it an "industrial" aspect, e.g. a bridge construction camp or something of that nature. The site was recommended for further study should it ever become part of an impact zone.

Another large historic trash scatter and feature complex was located in the Triangle block (48TE1482),along with a quartzite cobble reduction sequence (48TE1483). The historic site was an early 1900 's homestead or a school that was known to be in the area, and Park Historian Mike Johnson indicated that he would be responsible for determining its exact affiliation. The cobble scatter was interesting in that had a number of pieces that could be refit to study cobble reduction technology with more specificity. Site 48 TE398 was revisited and confirmed to be a small, ephemeral lithic scatter of low significance.

Work in the Moose Project Dornan's block revisited prehistoric site 48TE397 and determined that it had a diverse artifact assemblage and subsurface features, and accordingly some significance. Several large Early Historic foundations and debris middens were found in the area known to incorporate the historically significant Menor's Ferry site (48TE901). These and other materials had not been recorded previously, and indicate that the Ferry site has a much more definite archaeological signature than had been allowed for in previous historical reviews. It is more deserving of further review and protection as a result.

\section{RECONNAISSANCE SURVEYS AND SITE REVISITS}

\section{Blacktail Butte Western Transect and East Site Revisits}

Blacktail Butte, a large mountainous feature in the southern end of Grand Teton, was known to have 
a series of significant archaeological sites after work there during the SUNY era (e.g. Wright and Marceau 1981). NPS MWAC personnel conducted a few investigations in or near to it as well (e.g. Conner and Winchell 1991a, 1991b). Rising more than $1000 \mathrm{ft}$. above the surrounding basin floor, this glaciated fault block apparently offered a number of resources including diverse ecological settings, springs and small streams, and chippable stone. Tensleep formation quartzite quarries along its southern margin are apparently the most definite non-obsidian lithic procurement zone in Jackson Hole.

Wright and Marceau (1981) reported briefly on test excavations at Site 48TE391, which yielded numerous flakes, bone fragments, and tools made from obsidian, chert and quartzite. Obsidian hydration dates are somewhat questionable because they were derived before the need for ground temperature corrections was known, but they do provide reasonable estimates within at least 2 or 3 centuries. These dates clearly demonstrate a Middle Archaic age ca. 3500-4000 B.P. for at least some site components. Survey and testing several other sites (e.g. 48TE350-354) produced relatively dense artifacts, grinding stones, a tipi ring, and additional obsidian hydration dates ranging into the late Late Archaic or early Late Prehistoric period (ca. 2000 B.P.)

The presence of numerous sites, large and relatively unique site zones such as the quarries, and relatively rich buried components indicated that this would be an appropriate area to initiate a site revisit program in 1998 (Bartholomew, Peterson and Reher 1999b; additional UW/GTNP CAP work was conducted during the 1999 season (cf. Bartholomew and Reher 2000d). A complex transect was developed from the flats well south of Blacktail Butte along and up its western side. A second site of previously recorded sites on the east/southeast side of the butte were the subject of revisits although we did less extensive and systematic evaluations.

New sites discovered during the transect survey included a lithic scatter with an Early Historic component site with trash scatters and foundation (49TE1486), unfortunately recently burned, but with good subsurface potential), three lithic scatters, campsites or procurement areas (e.g. 48TE1487, 1488, 1489), and another small historic trash scatter (48TE1490). A larger number of sites were revisited, including 48TE350-354, 48TE381, 48TE385-88, 48TE391, 49TE400, 401/523, and 402 (Table 2). Several of the sites received extensive remapping, inventory of surface artifacts, and other procedures as part of an updated evaluation. A large number of the others were revisited and evaluation of their status was upgraded. More extensive work in the largest quartzite procurement zone was beyond the scope of the current reconnaissance.

\section{Cascade Canyon/Lake Solitude Reconnaissance}

Having been informed about archaeological materials around Lake Solitude by local residents, a reconnaissance of this area was planned. No archaeological work had been conducted in this high altitude zone in the central Teton range, and it was thought that even the most basic sort of information, e.g. surface lithic types and densities, would be useful for comparison to the basin-floor sites. A hike of ca. 16 $\mathrm{km}$ (10 miles) one way was necessary to achieve this goal. Unfortunately, during the July session used for the reconnaissance, the lake margins were still snow covered and the site location could not been confirmed (Bartholomew and Reher 1999a).

The Lake Solitude project is listed in the "reconnaissance" section of this report since that was the primary purpose at that juncture. However, Cascade Canyon Trail used to reach the area was subjected to an intensive, "Class III Inventory" level of coverage while it was being traversed. The trail rut, the edges of drainages crossed by the trails, rodent mounds along the trail corridor, and other features were inspected. It is always part of our purpose to establish coverage on this level to the extent possible in case future GTNP planning can utilize the survey for clearance purposes. This proved to be the case two years later when a few trail maintenance locations needed that clearance.

\section{Snake River Terraces/Blacktail Ponds, Cottonwood Creek Areas}

Another more substantial reconnaissance/ revisit project took place in $t$ wo locations a long the Snake River valley (Bartholomew and Reher 1999b). Once again, the occurrence of known sites and a desire to add to our knowledge about a specific environmental setting dictated selection of the sample area.

Sites in the Blacktail Ponds Overlook area were first recorded by Wright in 1973 (48TE405, 406). (Wright 1975). The juxtaposition of the north end of Blacktail Butte, the confluence of Ditch Creek and the Snake River, and other "ecotonal" features would have made the general area one of the more attractive habitation areas for all prehistoric hunter-gatherers. It is not surprising that the diffuse surface scatters of lithic 
debitage and firecracked rock found there stretch out for several hundred meters. Unfortunately, the most dense part of 48 TE 405 were destroyed by construction of parking lots. A large, previously unrecorded early historic site with trash scatters and foundation adds to the complexity of what remains of the site. Site 48TE406 is nearby and is a similar prehistoric accumulation. Middle Archaic diagnostics projectile points have been reported for both sites, and the probably should be considered as one site complex.

Another similar site complex was relocated across the Snake River along the mouth of Cottonwood Creek (48TE614, 615). Sites 48TE611, 614, and 615 had not received much attention since being reported by Wright and Marceau in 1976 . These sites were easily relocated because of the large diffuse surface scatters of chipped stone and firecracked rock. These two main sites are on adjacent upper and lower terrace zones and should be re-evaluated as one site complex. Diagnostic projectile points observed at the sites indicate their occupation may extend back to the Early Archaic period, i.e. 6000 years ago or more. Another site reported by Wright, 48TE611, could not be specifically relocated, although one Late Paleoindian Cody Complex point (ca. 8,000 B.P.) was found there.

Detailed documentation and other information was upgraded for all four sites in the 2 blocks, although additional research on the historic site, test excavation and other procedures still would be needed for a complete evaluation. On the order of 50 to 100 surface lithics were found and documented in each site area on the basis of this very basic and quick revisit. Although relatively low compared to surface manifestations in other areas, these surface artifacts always reflect much higher subsurface densities, and indicate that these are probably among the more significant sites in Grand Teton National Park.

\section{Jenny Lake South and String Lake}

A set of sites around the inlets and outlets of Jenny Lake and String Lake received a lot of attention from both SUNY and MWAC investigators. This was partly due to the fact that, as would be expected in such an environmental setting, this is one of the larger site complexes in Grand Teton. Their work also was at least partly because this area has among the highest visitation levels and most development, leading to a continuing need to monitor and evaluate the effects of various types of impact. Six sites were revisited there during the 1998 season, and some initial documentation was accomplished, including sites such as 48TE411, $412,414,576,1282$, and 1283 . These include large and small lithic scatters and a large historic site (1282), the location of a CCC construction camp and later Park employee housing. Site 414 , which is scattered in and around the existing Jenny Lake visitor center, was the main location for the previous studies by both the SUNY and MWAC teams and our more recent work. A fair density of subsurface lithics, datable fire hearths, and diagnostic artifacts from their work and ours indicate occupations extending from the Late Prehistoric back to include at least 2 Paleoindian eras (Cody and Hell Gap/Haskett). The UW/GTNP CAP study continued in 1999, and the main results from both years are incorporated in that report (Bartholomew and Reher 2000b).

\section{Beaver Creek Reconnaissance}

During the Moose Visitor Center project a judgmental survey transect was walked from the north end of the Moose Triangle block out to the north and swinging back to the south side of the block, for a total of about $5 \mathrm{~km}$. ( 3 miles). Various projects such as the Moose Visitor Center, the Blacktail Ponds and Cottonwood Creek reconnaissance, and the north end of the Black Tail Butte reconnaissance were giving us a good "quasi-transect" across the southern end of the Park, and a look at the zone further to the west was desirable. No sites were found, due at least in part to dense vegetation and leaf litter. A previously known site (48TE498) was revisited, although not recorded in any detail, it did confirm the presence of rather substantial sites in settings on benches above marshes and ponds, well back into the "foothills" and quite some distance from main drainages.

\section{SUMMARY}

A series of investigators have conducted archaeological research in Grand Teton National Park for more than 25 years, including teams from State University of New York, the National Park Service Midwest Archaeological Center, the University of Wyoming in various guises, and a series of CRM firms and in-house NPS archaeologists. Research has been somewhat hindered by the lack of continuity from the rather episodic involvement of these various parties, as well as by other factors such as poor ground visibility and active geological regimes that are not conducive to site preservation. Although this is not that dramatically different than the investigative histories of other regions, striving for more consistent methods and theoretical frameworks would be very desirable. Revisits and updated evaluations of numerous sites 
recorded very briefly 15 or 20 years ago are also greatly needed.

The 1998 season saw the first fieldwork by the writer and UW staff and students as part of a potentially long term cooperative project designed to overcome some of those limitations. A high level of activity during relatively brief field sessions resulted in work at 16 locations, including the discovery of 14 new sites and revisits to 30 more. The subsequent 1999 field sessions more than doubled all of these totals, while the 2000 season concentrated on research at one of the more significant site finds (to be detailed in subsequent reports; even so, a few new sites were found and other sites were revisited)..

The UW/GTNP Project has developed a library section for relevant literature, developed a standardized set of procedures and recording formats, and other materials. A series of technical reports, presentations at scientific conferences, public presentations, use of UW/GTNP CAP materials in several classes, and a Master's thesis also have resulted from the cooperative project. The UW/GTNP Cooperative Archaeology Project would intend to develop increased use of local historical resources and tribal ethnohistories as well, and all of the frameworks listed above should contribute to more interpretation in museums and other public settings.

Projects up to now have included small and medium-sized compliance surveys, inventory and site evaluations in areas with high levels of visitation or areas slated for facilities development (including increasing amounts of test excavations), areal reconnaissance surveys and site revisits, staff and field school training exercises, a geoarchaeological reconnaissance looking for older site deposits, and several other project types. The specifics of these various project locations and results were outlined just above so less needs to be said here. Of the more than 55 sites which we revisited, the majority had some very definite difference from what had been recorded previously. Many were larger and more complex than had been recorded, while others might be have very few or no artifacts visible where many had once been reported. A few had received increasing amounts of impact from heavy visitation and so on, and all of these matters are informative for future management purposes. For many of the sites revisited, our work resulted in the first detailed maps and surface artifact inventories yet done there.

With the discoveries in recent years, nearly 450 archaeological sites are now known for Grand
Teton Park and the adjacent Rockefeller Parkway (several hundred more if adjacent portions of National Forests and Yellowstone National Park are included). Increasing numbers of radiocarbon dates, obsidian hydration dates, and archaeomagnetic dates have enhanced the details of the regional chronology, although these usually derive only from intense excavation work. The chronology of Jackson Hole is still not completely understood. Increasing evidence of some sort of affiliations with all surrounding regions is another result of such work, not just the Northwest Plains as once tended to configure most research objectives. Obsidian source analysis, studies of site microstratigraphy formation processes, climatic reconstruction and many other frameworks can now be applied in much more detail.

A series of more broad cultural ecology research frameworks also have emerged from the last several decades, primarily aimed at furthering our understanding of prehistoric adaptation in high altitude environments. Originally viewed as marginal at best, perspectives on mountain basins have shifted to expect at least regular seasonal use with a well e stablished system of base camps and satellite sites. The potential richness of a number key animal and plant resources has been established and the presence of year-round occupations, requiring substantial housing structures and specialized storage strategies, are now considered a possibility in many high altitude zones, at least during some eras.

The numerous surface surveys conducted by UW/GTNP CAP and other groups is producing better understanding of the general parameters of prehistoric settlement patterns. Like all high altitude zones, Jackson Hole is structured by a series of linear "resource patches" along drainages, other resource patches around the larger lakes, especially at inlets and outlets, as well as resources patches of different shapes at marshes and smaller lakes and ponds, and several other resource structures. Site concentrations have now been well documented at several of the more productive settings, and the patterned nature of scatters of smaller sites in other settings is beginning to emerge.

\section{LITERATURE CITED}

Adams, Richard. 1993 High Altitude Resources and Adaptation: Steatite Use in Wyoming. Paper Presented at the First Biennial Rocky Mountain Anthropological Conference, Jackson, Wyoming. 
Baker, R.G. 1970. Pollen Sequence from Late Quaternary Sediments in Yellowstone Park. Science 168:1449-1450.

Barnosky, C.W. 1987. Late Glacial and Postglacial Vegetation and Climate of Jackson Hole and the Pinyon Peak Highlands, Wyoming. UWNPS Research Project No. 18 Submitted to the University of Wyoming-National Park Service Research Center, Laramie, Wyoming.

Bartholomew, Alan L. n.d. Prehistoric Occupational Intensity in Relation to Paleoclimate in Jackson Hole, Northwestern Wyoming. Master's Thesis Draft Manuscript on File, Department of Anthropology, University of Wyoming, Laramie.

Bartholomew, Alan .L., Michael R. Peterson, and Charles A. Reher. 1999a. Archaeological Inventory for the Proposed Gros Ventre Campground RV Facilities, Grand Teton National Park, Wyoming. Report on file, Grand Teton National Park, University of Wyoming Department of Anthropology.

1999b. Archaeological Research at and Around Blacktail Butte, Grand Teton National Parks, Wyoming: Site Revisits and Survey. Report on file, Grand Teton National Park, University of Wyoming Department of Anthropology.

2000 Archaeological Inventory for the Proposed Moose Visitor Center at the Moose Junction Area, Grand Teton National Park. Report on file, Grand Teton National Park, University of Wyoming Department of Anthropology.

Bartholomew, Alan L. and Charles A. Reher. 1998Archaeological Inventory for the Triangle X Ranch. Report on file, Grand Teton National Park, University of Wyoming Department of Anthropology.

1999a Archaeological Inventory of Cascade Canyon and Lake Solitude, Grand Teton National Park. Report on file, Grand Teton National Park, University of Wyoming Department of Anthropology. 1999b Archaeological Surveys on the Snake River T erraces: Cottonwood Creek and Blacktail Ponds. Report on file, Grand Teton National Park, University of Wyoming Department of Anthropology.

1999c Archaeological Inventory and Site Testing at Oxbow Bend: Grand Teton National Park. Report on file, Grand Teton National Park, University of Wyoming Department of Anthropology.

1999d UW/GTNP Archaeological Program Procedure Manual. M.S. on File, Department of Anthropology, University of Wyoming, Laramie.

2000a Archaeological Reconnaissance and Site Revisits at Colter Bay and Portions of the Eastern Shore of Jackson Lake, Grand Teton National Park. Report on file, Grand Teton National Park, University of Wyoming Department of Anthropology.

$2000 \mathrm{~b}$ Archaeological Inventory of the South Jenny Lake Developed Area and String Lake Area, Grand Teton National Park. Report on file, Grand Teton National Park, University of Wyoming Department of Anthropology.

2000c Archaeological Reconnaissance of the Berry and Owl Creek Areas: Grand Teton National Park. Report on file, Grand Teton National Park, University of Wyoming Department of Anthropology.

2000d Archaeological Investigation of a Rock Alignment Near the Potholes: Grand Teton National Park. Report on file, Grand Teton National Park, University of Wyoming Department of Anthropology. 
2000e Archaeological Inventory of Lupine Meadows and Cottonwood Creek, Grand Teton National Park. Report on file, Grand Teton National Park, University of Wyoming Department of Anthropology.

$2000 \mathrm{f}$ Archaeological Inventory of the Mormon Row District, Grand Teton National Park. Report on file, Grand Teton National Park, University of Wyoming Department of Anthropology.

2000g Archaeological Reconnaissance at the Gros Ventre Campground, 1999: Grand Teton National Park. Report on file, Grand Teton National Park, University of Wyoming Department of Anthropology.

2000h Preliminary Report on the Archaeological Inventory and Site Testing at Kelly Warm Springs: Grand Teton National Park. Report on file, Grand Teton National Park, University of Wyoming Department of Anthropology.

2000i Archaeological Investigations At and Around 48TE403, Ditch Creek Area, Grand Teton National Park. Report on file, Grand Teton National Park, University of Wyoming Department of Anthropology.

2000j Archaeological Reconnaissance of Cow Lake, Grand Teton National Park. Report on file, Grand Teton National Park, University of Wyoming Department of Anthropology.

Bender, Susan J.

1983 Hunter Gatherer Subsistence in a Mountainous Environment: The Prehistory of the Northem Tetons. Unpublished PhD Dissertation, State University of NewYork, Albany.

Bender, Susan J., and Gary A. Wright

1988 High-Altitude Occupations, Cultural Process, and High Plains Prehistory. American Anthropologist 90(3): 619-639.
Benedict, James B.

1992 Footprints in the Snow: High-Altitude Cultural Ecology of the Colorado Front Range, U.S.A. Arctic and Alpine Research 24(1):1-16.

Benedict, James B. and Byron L. Olson

1978 The Mount Albion Complex: A Study of Prehistoric Man and the Altithermal. Research Report No. 1, Center for Mountain Archaeology, Ward, Colorado.

Black, Kevin D.

1991 Archaic Continuity in the Colorado Rockies: The Mountain Tradition. Plains Anthropologist 36(133):1-29.

Calabrese, Francis A., and E. Christopher Svee. 1987) Analysis of Grand Teton Projectile Point Morphology. Appendix 1 in: Site Testing at Jackson Lake: A Jackson Lake Archaeological Project Interim Report. By Melissa A. Connor. Ms. On File, National Park Service, Midwest Archeological Center, Lincoln, Nebraska.

Cannon, Kenneth P. 1988. Evidence of Prehistoric Bison Exploitation from the Upper Snake River, Grand Teton National Park, Wyoming. Paper Presented at the $46^{\text {th }}$ Annual Plains Anthropological Conference, Wichita, Kansas.

1991 Faunal Remains from Grand Teton National park, Wyoming, In Jackson Lake Archaeological Project: the 1987 and 1988 Field Work, Volume I, By M.A.. Conner, K.P. Cannon, S.E.. Matz, D.C. Carlevato, and C.A. Winchell, pp. 265-301,493-578. Midwest Archaeological Center, Technical Report No. 7, Lincoln, Nebraska.

1997 A Review of Prehistoric Faunal Remains from $V$ arious Contexts in Yellowstone National Park, Wyoming. Report on File, Midwest Archaeological Center, Lincoln, Nebraska.

1999 Archaeology and Bison Management in Yellowstone National park. Paper Presented at the $64^{\text {th }}$ Annual Meeting of the Society for American Archaeology, Chicago, Illinois. 
n.d. A Reassessment of Prehistoric Bison In Jackson Hole, Wyoming: New Evidence from the Goetz Site (48TE455). Report on File, Midwest Archaeological Center, Lincoln, Nebraska.

Cannon, Kenneth P., William Eckerle, and Kenneth L. Pierce n.d. Geoarchaeological Investigations of the Crescent Ranch Site (48TE1079), Teton County, Wyoming. Report on File, Midwest Archaeological Center, Lincoln, Nebraska.

Cannon, Kenneth P., and Mehgan Sittler n.d. Rodent and Badger Remains from Terminal Pleistocene-Holocene Deposits in Southern Jackson Hole, Wyoming. Report on File, Midwest Archaeological Center, Lincoln, Nebraska.

Cannon, Kenneth P., and Jamie Schoe. 1993 Cultural Chronology of the Greater Yellowstone Area. Paper Presented at the first Biennial Rocky Mountain Anthropological Conference, Jackson, Wyoming.

Connor, Melissa A. 1985. An Archaeological Reconnaissance of Jackson Lake: A Preliminary Report. Manuscript on file, National Park Service, Midwest Archeological Center, Lincoln, Nebraska.

1989 Jackson Lake Archaeological Project, 1985: An Interim Report. Ms. On File, National Park Service, Midwest Archeological Center, Lincoln, Nebraska.

1990a Site Testing at Jackson Lake: A Jackson Lake Archaeological Project Interim Report. Ms. On File, National Park Service, Midwest Archeological Center,Lincoln, Nebraska.

1990b Archaeological Block Inventory of the South Jenny Lake Developed Area. Rocky Mountain Region Archaeological Project, February 1989. Manuscript on file, National Park Service, Midwest Archaeological Center, Lincoln, Nebraska. 1992a A Preliminary Report on Mitigation and Testing at 48TE414, 48TE411, and 48TE1283, Grand Teton National Park. Rocky Mountain Region Archeological Project Report. Ms. On File, National Park Service, Midwest Archeological Center, Lincoln, Nebraska.

1992b Jenny and String Lake Mitigation Plan, Grand Teton National Park: 1992 Addendum. Manuscript on file, National Park Service, Midwest Archaeological Center, Lincoln, Nebraska.

1995 Archaeological Investigations at the Jenny Lake Developed Area, Grand Teton National Park, Wyoming. National Park Service, Midwest Archeological Center, Technical Report No.33. Lincoln, Nebraska.

1998 Final Report on the Jackson Lake Archaeological Project, Grand Teton National Park, Wyoming. National Park Service, Midwest Archeological Center, Technical Report No. 46. Lincoln, Nebraska.

Connor, Melissa A., Kow-ling Chyi, and Denise C. Carlevato. 1991. Ceramics and Clay Nodules from Jackson Lake, Wyoming: Description and Mineralogical Analysis. Plains Anthropologist 36(135):153-170.

Connor, Melissa A., and Raymond Kunselman. 1997. Mobility, Settlement Patterns, and Obsidian Source Variation in Jackson Hole, Wyoming. Tebiwa 26(2):162-175.

Connor, Melissa A., Kenneth L. Pierce, Scott Lundstrom, and John M. Good. 1998. Final Report on the Jackson Lake Archeological Project, Grand Teton National Park, Wyoming. Ms. On File, National Park Service, Midwest Archeological Center, Lincoln, Nebraska. 
Connor, Melissa A., and Coleen Winchell. 1991a.Archeological Inventory for a Trail on Blacktail Butte, Grand Teton National Park, Wyoming. Rocky Mountain Region Archaeological Project Report. Ms. On File, National Park Service, Midwest Archeological Center, Lincoln, Nebraska.

1991b Archaeological Inventory of Cottonwood Creek Pullout, Grand Teton National Park, Wyoming. Rocky Mountain Region Archeological Project Report. Ms. On File, University of Wyoming, Department of Anthropology, Laramie.

Cummings, Linda Scott. 1989. Pollen and Macrofloral Analysis at Nine Sites in Teton National Park, Wyoming: 1988 Field Season. Manuscript on file National Park Service, Midwest Archaeological Center, Lincoln, Nebraska.

1996 Paleoenvironmental Interpretations for the Mill Iron Site: Stratigraphic Pollen and Phytolith Analysis. In The Mill Iron Site, George C. Frison (ed.). University of New Mexico Press, Albuquerque, New Mexico, pp. 177-193.

Fredlund, G. 1995. Pollen and Phytolith Analysis of the Henn Site. In The Henn Site (48TE1291): Early Archaic to Protohistoric Occupation at the Jackson National Fish Hatchery, Wyoming. Technical Report No. 7, Mary Lou Larson (ed.), pp. 217-222. Department of Anthropology, University of Wyoming, Laramie.

Frison, George C. 1976. The Chronology of the Paleo-Indian and Altithermal Cultures in the Big Horn Basin, Wyoming. In: Culture Change and Continuity: Essays in Honor of James Bennett Griffin, Charles E. Cleland (ed.). Academic Press, New York, pp. 147174.

1978 Prehistoric Hunters of the High Plains. ( $1^{\text {st }}$ Ed.) Academic Press, New York.
1991 The Foothills-Mountains the Open Plains: The Dichotomy in Paleoindian Subsistence Strategies Between Two Ecosystems. In Ice Ace Hunters of the Rockies, D.J. Stanford and J.S. Day eds. Denver Museum of Natural History and University Press of Colorado, Niwot. PP 323-342.

1992a Prehistoric Hunters of the High Plains. ( $2^{\text {nd }} E d$.) Academic Press, San Diego

1992b The Foothill Mountain Late Paleoindian and Early Plains Archaic Chronology and Subsistence. In: Changing Perspectives of the Archaic on the Northwest Plains and Rocky Mountains, Mary Lou Larson and Julie E. Francis (eds.). University of South Dakota Press, Vermillion. Pgs. 85-105.

Frison, George C., and Donald C. Grey. 1980. Pryor Stemmed, A Specialized Late Paleoindian Ecological Adaptation. Plains Anthropologist 25(87):27-46.

Frison, G.C., and W.P. Eckerle, R. Adams, and E.E. Ingbar. 1989. Report on Geoarchaeological Research and Archaeological Research in the Jackson Lake Reservoir Pool Area, 1988. Manuscript on file, Midwest Archaeological Center, National Park Service, Lincoln, Nebraska.

Frison, G.C., E.E. Ingbar, and W.P. Eckerle. 1988. Geoarchaeological Research and Archaeological Research in the Jackson Lake Reservoir Pool Area, 1987. Manuscript on file, Midwest Archaeological Center, National Park Service, Lincoln, Nebraska.

Gish, Jennifer W. 1986. Pollen Results from 48TE545/546, Grand Teton, Wyoming. Manuscript on file National Park Service, Midwest Archaeological Center, Lincoln, Nebraska. 
Johnson, Ann M. 1997. Archeological Inventory for the Granite Cabin Grand Teton National Park. Rocky Mountain Cluster National Park Service Archeological Project Report. Ms. On File, University of Wyoming, Department of Anthropology, Laramie.

Kelly, Robert L. 1999. Early Holocene Archaeology in Grand Teton National Park. Ms. On File, University of Wyoming, Department of Anthropology, Laramie.

Kornfeld, M. and M. L. Larson. 1993. Change and Continuity in Early to Mid-Holocene Central Rocky Mountain Technology. Paper presented at the Society for American Archaeology Meetings, St. Louis, Missouri. April 1993.

1994 Betwixt and Between the Basin and the Plains: The Limits of Numic Expansion. In Across the West: Human Population Movement and the Expansion of the Numa, edited by D.B. Madsen and D. Rhode, pp. 200-210. University of Utah Press, Salt Lake City, Utah.

Kornfeld, M. and D.J. Rapson. 1995. Dating: Radiocarbon Assays, Archaeomagnetic Analyses, Obsidian Hydration, and Index Fossils. In The Henn Site (48TE1291): Early Archaic to Protohistoric Occupation at the Jackson National Fish Hatchery, W yoming. Technical Report No. 7, edited by Mary Lou Larson, pp. 225-231. Department of Anthropology, University of Wyoming, Laramie.

Kunselman, R., Kornfeld, M., and J.C. Miller. 1995Raw Material Types and Sources: Chipped Stone, Fire Altered Rock, and Obsidian XRF Analysis. In The Henn Site (48TE1291): E arly Archaic to Protohistoric Occupation at the Jackson National Fish Hatchery, Wyoming. Technical Report No. 7, Mary Lou Larson (ed.), pp. 79-82. Department of Anthropology, University of Wyoming, Laramie.
Larson, Mary Lou. 1995a. The Henn Site (48TE1291): Early Archaic to Protohistoric Occupation at the Jackson National Fish Hatchery, Wyoming. Technical Report No. 7, Mary Lou Larson (ed.), Department of Anthropology, University of Wyoming, Laramie.

1995b Chipped Stone Technological Organization. In The Henn Site (48TE1291): Early Archaic to Protohistoric Occupation at the Jackson National Fish Hatchery, Wyoming. Technical Report No. 7 , Mary Lou Larson (ed.), pp. 85-106. Department of Anthropology, University of Wyoming, Laramie.

Larson, M.L. and D.J. Rapson. 1995. Introduction, Theoretical Orientation, and Research Questions. In The Henn Site (48TE1291): Early Archaic to Protohistoric Occupation at the Jackson National Fish Hatchery, Wyoming. Technical Report No. 7, Mary Lou Larson (ed.), pp. 2-12. Department of Anthropology, University of Wyoming, Laramie.

Larson, Mary Lou, Marcel Kornfeld, and David J. Rapson (eds.). 1995. High Altitude HunterGatherer Adaptations in the Middle Rocky Mountains: 1988-1994 Investigations. Technical Report No. 4, Department of Anthropology, University of Wyoming, Laramie.

Lohse, E.S. and Richard N. Holmer. 1990. Fort Hall and the Shoshone-Bannock. Idaho State University Press, Pocatello.

Love, C.M. 1972. An Archaeological Survey of the Jackson Hole Region, Wyoming. M.A. Thesis, Department of Anthropology, University of Wyoming, Laramie.

Marceau, Thomas E. 1976. Cottonwood Creek: A Preliminary Model for Springtime Riverine Adaptation in Jackson Hole, Wyoming. Paper Presented at the $34^{\text {th }}$ Annual Plains Conference, Minneapolis, Minnesota. 
Matz, Stephan E. 1988. Projectile Point Classification and Chronology of the Northern Jackson Lake, Wyoming Archaeological Sites. Manuscript on file, National Park Service, Midwest Archeological Center, Lincoln, Nebraska.

Miller, J.C. 1995. Geology of the Henn Site. In The Henn Site (48TE1291): Early Archaic to Protohistoric Occupation at the Jackson National Fish Hatchery, Wyoming. Technical Report No. 7, Mary Lou Larson(ed.), pp. 201216. Department of Anthropology, University of Wyoming, Laramie.

Mulloy, W. 1958. A Preliminary Historical Outline for the Northwestern Plains. University of Wyoming Publications 22 ( 1 and 2).

Murphy, Robert F. and Yolanda Murphy. 1960. Shoshone-Bannock Subsistence and Society. Anthropological Records 16:7. University of California, Berkeley.

Peterson, Michael R. 1991. Obsidian Projectile Points from the Lawrence Site (48TE509) Near Jackson Lake in Northwestern Wyoming. The Wyoming Archaeologist 34(1-2):51-66.

Peterson, Michael R., Alan L. Bartholomew, and Charles A. Reher. 1998a. Archaeological Inventory for the National Parks Service Proposed Visitor's Campus at Jackson. Report on file, Grand T eton National Park, University of Wyoming Department of Anthropology.

1998b Archaeological Inventory for the Jenny Lake Overlook, Grand Teton National Park. Report on file, Grand Teton National Park, University of Wyoming Department of Anthropology.

1998c Archaeological Survey for the Colter Bay Trail Rehabilitation. Report on file, Grand Teton National Park, University of Wyoming Department of Anthropology

Quick, Kelly. 1995. Grand Teton National Park Climbers Ranch/Highlands Ranch Area, Teton County, Wyoming. Ms. On File, University of Wyoming, Department of Anthropology, Laramie.
Rapson, D.J. 1995a. Faunal Analysis. In The Henn Site (48TE1291): Early Archaic to Protohistoric Occupation at the Jackson National Fish Hatchery, Wyoming. Technical Report No. 7, Mary Lou Larson (ed.), pp. 133162. Department of Anthropology, University of Wyoming, Laramie.

Rapson, D.J., M., Kornfeld, and M.L. Larson. 1995.Spatial Distribution and Analysis of the Main Excavation Block. In The Henn Site (48TE1291): E arly Archaic to Protohistoric Occupation at the Jackson National Fish Hatchery, Wyoming. Technical Report No. 7, Mary Lou Larson (ed.), pp. 169-199. Department of Anthropology, University of Wyoming, Laramie.

Reeve, Stuart A. 1976. Plant Resources and Prehistoric Transhumance in Jackson Hole, Wyoming. Manuscript on file, National Park Service, Midwest Archeological Center, Lincoln, Nebraska.

1983 The Lizard Creek Sites (48TE700 and 48TE701): The Prehistoric Root Gathering Economy of Northern Grand Teton National Park, Northwestern Wyoming. Manuscript on file, National Park Service, Midwest Archaeological Center, Lincoln, Nebraska.

1986 Root Crops and Prehistoric Social Process on the Snake River Headwaters, Northwestern Wyoming. $\mathrm{PhD}$. Dissertation, Department of Anthropology, State University of New York, Albany.

Reher, Charles A., and Laura L. Scheiber. 1995.Tree Growth on the Snake River Flood Plain, Jackson Hole, Wyoming: A Dendrochronology Project. Wetlands Research Program Technical Report WRPRE-9, US Army Corps of Engineers, Waterways Experiment Station, Washington, D.C. 
Reher, Charles A., Rick Weathermon, Clint Crago, Sara Sheen, Alan Bartholomew, and Robert Kelly. 2000. The Cow Lake Site (48TE1536), An Early Historic Stone Circle Site in Grand Teton National Park. Paper Presented at the Joint Midwest Archaeological/Plains Anthropological Conference, St. Paul, Minnesota.

Schoen, James R. 1997. As Clear as Opaque Obsidian: Source Location in Jackson Hole, Wyoming. Tebiwa 26(2):216-224.

Scott, Linda J. 1987. Pollen and Macrofloral Analyses of Four Sites Around Jackson Lake, Wyoming. Manuscript on file, National Park Service, Midwest Archeological Center, Lincoln, Nebraska.

Shimkin, D.B. 1947. Wind River Shoshone Ethnogeography. Anthropological Records 5:4. University of California Press, Berkeley.

Sittler, Mehgan, and Kenneth P. Cannon. 2000. Fourteen Thousand Years of Rodents: A Record from Southern Jackson Hole, Wyoming. Paper Presented at the Joint Midwest Archaeological/Plains Anthropological Conference, St. Paul, Minnesota.

Truesdale, James A. 1994. Archaeological Survey of the Spread Creek and Moran Junction Areas and Environs, Grand Teton National Park, Teton County, Wyoming. Ms. On File, University of Wyoming, Department of Anthropology, Laramie.

Waddington, J.C.B., and H.E. Wright, Jr. 1974. Late Quaternary Vegetation Changes on the East Side of Yellowstone Park, Wyoming. Quaternary Research 4:175-184.

Whitlock, Cathy, and P.J. Bartlein. 1993. Postglacial Vegetation and Climate of Grand Teton and Southern Yellowstone National Parks. Ecological Monographs 63:173-198.
Winfrey, James V. 1991. Package 171B2: Reconstruct Park Road, South Jenny Lake to North Jenny Lake: Archeological Project Research Design and Data Recovery Plan for Site 48TE414 Jenny Lake, Grand Teton National Park, Wyoming. Rocky Mountain Region Archeological Data Recovery Plan. Ms. On File, National Park Service, Midwest Archeological Center, Lincoln, Nebraska.

1994 Archaeological Investigations at Site 48TE412, String Lake, Grand Teton National Park, Wyoming. Midwest Archeological Center Technical Report No. 35, Lincoln, Nebraska.

Wright, Gary A. 1975. A Preliminary Report on the Archaeology of the Jackson Hole Country, Wyoming. Department of Anthropology, State University of New York, Albany.

1984 People of the High Country: Jackson Hole Before the Settlers. American University Studies Series XI Vol. 7. Peter Lang, New York.

Wright, Gary A., and Thomas E. Marceau. 1977. Archaeological Reconnaissance in Western Jackson Hole. Ms. On File, National P ark Service, Midwest Archaeological Center, Lincoln, Nebraska.

1981 Report on Excavations at Blacktail Butte. Report On File, National Park Service, Midwest Archaeological Center, Lincoln, Nebraska.

Wright, Gary A., and Stuart A. Reeve. 1976. A Preliminary Report on Two Ocean Lake 1 (48TE357): A Seasonal Camp in Grand Teton National Park. Ms. On File, National Park Service, Midwest Archeological Center, Lincoln, Nebraska. 